\title{
Problem Based Learning and Guided Inquiry Learning Model on Critical Thinking Ability
}

\author{
Suprapti Rejeki, Riyadi, Siswanto \\ Sebelas Maret University, Jalan Ir. Sutami No. 36A, Jebres, Surakarta 57126 Indonesia \\ e-mail: supraptir20@gmail.com
}

\begin{abstract}
This research aims to determine the distinction in students' critical thinking abilities who were taught by using the problem-based learning, guided inquiry learning, and conventional learning models. The population is all grade VIII students of public junior high schools in Bantul district in the 2019/2020 academic year. This study used stratified cluster random sampling to select 3 classes in each school. The pre-requisite test used was the balance test, normality test, and homogeneity test. The data collection technique used was a critical thinking ability test. The analysis technique of this research was two-way ANOVA with different cells. The results showed that the problem-based learning model had a significant positive effect on the critical thinking abilities compared to conventional learning. Meanwhile, there is no significant difference between students taught by problem-based learning and by guided inquiry learning, and between the guided inquiry learning and conventional learning, either.
\end{abstract}

Keywords: critical thinking, guided inquiry, problem-based learning

How to Cite: Rejeki, S., Riyadi, \& Siswanto. (2021). Problem Based Learning and Guided Inquiry Learning Model on Critical Thinking Ability. International Journal on Emerging Mathematics Education, 5(1), 61-68. http://dx.doi.org/10.12928/ijeme.v5i1.19939

\section{INTRODUCTION}

Education is the only appropriate means of building the human resources quality so that this country can advance (Siagian et al., 2021). With the existence of education, especially in mathematics, humans will try to develop themselves so that they can face advances in science and technology because mathematics has an important role in everyday life. Taking into account the importance of the role of mathematics, it is very worrying when looking at conditions in the Indonesia's performance in the Trends in International Mathematics and Science Study TIMSS which were not good since 1999.

The description above shows that student achievement is not optimal due to the low critical thinking abilities of students. One of the abilities that students must have when facing problems and challenges in social life is the ability to think critically because learning mathematics makes students not only learn mathematics material but also learn how to deal with problems and challenges in social life (Agoestanto \& Sukestiyarno, 2017). Critical thinking needs to be developed in mathematics learning because critical thinking allows students to analyze their thoughts to make choices and draw conclusions (Sulistiani \& Masrukan, 2016). The observation results show that the percentage assessment of critical thinking indicators, namely identifying existing biases is $35.36 \%$, compiling and analyzing arguments of $39.67 \%$, analyzing the truth of statements by $44.68 \%$, and making conclusions of $35.36 \%$. The results of these observations indicate the low ability of students to think critically. Meanwhile, students with high critical thinking abilities tend to be faster to learn problems systematically, utilize ideas or information, identify information, formulate innovative statements, evaluate and modify them to produce the best ideas (Salimi et al., 2017). 
Therefore, it must be realized that it needs to be developed or improved regarding students' critical thinking abilities. Evaluations or tests that reflect critical thinking abilities are used to support increased critical thinking abilities (Jacob \& Chase, 1992). Besides, to improve students' critical thinking abilities, it is also necessary to pay attention to the development of the teaching and learning process. This is because various dominant factors, namely the leadership of the principal, teachers, media/devices/learning models, school facilities, and infrastructures such as books, libraries, and appropriate curricula affect even determine the quality of education (Wahyudi, 2010). Thus, teachers and learning models are the most important components in learning to correct abilities students' critical thinking.

Based on observations made in several schools, teachers still use conventional teacher-centered learning models, so they do not support students to be active in learning so that they can support the development of students' critical thinking abilities. Therefore, it is necessary to develop critical thinking abilities by providing appropriate learning models. Learning models that can be used are problem-based learning (PBL) and guided inquiry (GI) learning models. The problem-based learning model is a learning model where the teacher is only a facilitator and the learning is dominated by students (Siagian et al., 2021). When given the PBL model, students are required to think critically against subjects whose implementation is in real problems (Alandia et al., 2019). Students are required to work on real problems in problembased learning to compile their knowledge (Kusumah et al., 2020). Problem-based learning uses problems in everyday life as learning subjects that need solutions (Meke et al., 2018).

The guided inquiry learning model affects students' thinking patterns and student skills so that students can present challenging ideas/thoughts in learning mathematics. The first step of the GI learning model is that students find their problems, then the teacher guides students to encourage creative thinking so that they can find new ideas or discoveries (Anam, 2015). Guided inquiry can increase student activity (Widiana et al., 2020). This learning model begins with a question or problem then finds answers to scientific questions or problems (Hartono, 2013).

This research aims to decide the distinction in students' critical thinking abilities who were given the problem-based learning, guided inquiry, and conventional learning models. The hypothesis in this study is that there is a distinction in the critical thinking abilities of students who are given problem-based learning, guided inquiry, and conventional learning models. So, this research can be used to support previous research.

\section{RESEARCH METHOD}

This type of research is a quasi-experimental research, where we could not control all variables. The stages of quasi experimental research are as follows.

\section{Literature review}

We made observations at school to see the learning process and the obstacles experienced by students. Besides, we also provided description questions to identify mistakes and difficulties of students in solving problems. Furthermore, we read from various previous research sources and related books to overcome existing problems. 


\section{Problem identification and limitation}

We identified problems that students are unable to identify question information, analyze arguments, analyze the truth of the statements in the questions, and formulate conclusions well. Based on the identified problems, students have problems with critical thinking skills. The low ability of students to think critically can be improved by creating a conducive, student-centered learning process and training students independently to solve problems. The learning model that can be used is the problem-based learning and guided inquiry learning model. Then we limited the research problem related to the effect of problem-based learning, guided inquiry, and conventional (control class) learning models on critical thinking skills in mathematics learning in grade VIII students of public junior high schools in Bantul district for the 2019/2020 academic year.

\section{Hypothesis formulation}

Based on the existing problems and literature review, we formulated a hypothesis, namely that students who are given a problem-based learning model will produce better critical thinking skills than students who are given the guided inquiry learning model and conventional and students who are given the guided inquiry learning model will produce the ability critical thinking is better than students who are given conventional learning models.

\section{Research plan}

The population in this study were all grade VIII students of public junior high schools in the Bantul district for the 2019/2020 school year. The sample of this research is three public junior high schools in Bantul Regency. The sampling technique used was the stratified cluster random sampling technique. The subjects of this study were 269 students. The data collection technique used pre-test and post-test critical thinking skills in the form of description questions. There are four questions in the description used in each test with the material of flat-sided solid figures. The research design used in Table 1.

Table 1. Research design of $3 \times 1$

\begin{tabular}{cc}
\hline Learning Model $(\mathrm{X})$ & Critical Thinking Ability $(\mathrm{Y})$ \\
\hline Problem Based Learning $\left(\mathrm{X}_{1}\right)$ & $\mathrm{X}_{1} \mathrm{Y}$ \\
Guided Inquiry $\left(\mathrm{X}_{2}\right)$ & $\mathrm{X}_{2} \mathrm{Y}$ \\
Konvensional $\left(\mathrm{X}_{3}\right)$ & $\mathrm{X}_{3} \mathrm{Y}$ \\
\hline
\end{tabular}

We conducted the research procedure as follows.

Instrument validation

We validated the content related to the pre-test and post-test questions on critical thinking skills and the learning tools to be used. The content validation was carried out with three lecturers at Sebelas Maret University. After making several revisions, all instruments were said to be valid by the validator.

Instrument testing

The pre-test and post-test instruments for critical thinking skills were tested in a pilot school. The results of the pre-test and post-test critical thinking skills were then 
calculated for the distinguishing power of the items, the difficulty level of the questions, and the reliability test. The distinguishing power of the two test instruments is $r$ ( $p$ bis) $\geq 0.3$ so it is said to be good, the difficulty level of the two test instruments is $0.3 \leq \mathrm{P} \leq 0.7$ so it is said to be good, and the reliability test of the two instruments also obtained reliable results because $r_{11} \geq 0.7$.

Data collection pre-test critical thinking ability

After content validation and testing with good results, the instrument can be used for research. Before the experiment was carried out, the researcher gave students the pre-test of critical thinking skills both in the experimental class (problembased learning and guided inquiry learning models) and the control class (conventional learning).

\section{Experiment}

Researchers conducted an experimental class in the experimental class (problem-based learning and guided inquiry learning models). Control class is carried out by teachers who usually deliver material in class, namely the conventional model. This experiment was carried out for five meetings in three schools consisting of high, medium, and low schools. Each school uses three classes the experimental class 1 (problem-based learning), experiment 2 (guided inquiry), and the control class (conventional learning).

\section{Data collection post-test critical thinking ability}

When the experiment was completed, the researcher gave a post-test of critical thinking skills to students, both the experimental class and the control class.

Process and analyze data on critical thinking ability

After all the pre-test and post-test data for critical thinking skills were obtained, the researcher carried out the prerequisite test calculations, namely the balance test, normality test, and homogeneity test. All prerequisite tests were fulfilled, then the analysis of variance (ANOVA) test was carried out.

Preparation of reports

Researchers compile reports according to the research results that have been obtained. If the research is not following the hypothesis, then the researcher assumes because it does not match the hypothesis based on the conditions of the student, teacher, and school concerned.

\section{RESULTS AND DISCUSSION}

We conducted a prerequisite test, where there was a balance test, normality test, and homogeneity test. The results of the balance test are provided in Table 2.

Table 2. The result of the balance test

\begin{tabular}{lcc}
\hline & \multicolumn{2}{c}{ Levene's Test for Equality of Variances } \\
& $\mathrm{F}$ & Sig \\
\hline $\begin{array}{l}\text { Equal Variance } \\
\text { Assumed }\end{array}$ & 0.624 & 0.430 \\
\hline
\end{tabular}

IJEME, Vol. 5, No. 1, March 2021, 61-68. 
Table 2 shows that sig $>0.5$ so that $\mathrm{H}_{0}$ is not rejected. Therefore the population sample has a balanced initial condition. The next is the normality test as provided in Table 3.

Table 3. The result of the normality test

\begin{tabular}{cccc}
\hline & PBL & GI & Conventional \\
\hline Test statistic/ L Max & 0.074 & 0.078 & 0.085 \\
Liliefors Table & 0.094 & 0.094 & 0.093 \\
\hline
\end{tabular}

Based on table 3, it is known that for PBL having $\mathrm{L}$ Max $=0.074<\mathrm{L}$ table $=0.094$ then $\mathrm{H}_{0}$ is not rejected, which means that all research samples for PBL come from a normally distributed population. For GI has $\mathrm{L}$ Max $=0.078<\mathrm{L}$ table $=0.094$, then $\mathrm{H}_{0}$ is not rejected, which means that all research samples for GI come from populations that are normally distributed. For conventional, it has $\mathrm{L} \mathrm{Max}=0.085<\mathrm{L}$ table $=0.093$ then $\mathrm{H}_{0}$ is not rejected, which means that all research samples for GI come from normally distributed populations.

Table 4. The result of the homogeneity test

\begin{tabular}{cccccc}
\hline & & Levene Statistic & $\mathrm{df}_{1}$ & $\mathrm{df}_{2}$ & Sig. \\
\hline Critical Thinking & Based on Mean & 0.301 & 2 & 266 & 0.740 \\
\hline
\end{tabular}

Table 4 shows that sig $>0.05$, then $\mathrm{H}_{0}$ is not rejected, which means that the sample comes from a homogeneous population.

Table 5. The result of ANOVA

\begin{tabular}{lccccc}
\hline & Sum of Squares & df & Mean Square & F & Sig. \\
\hline Between Groups & 724.295 & 2 & 362.148 & 3.434 & 0.034 \\
Within Groups & 28056.060 & 266 & 105.474 & & \\
Total & 28780.355 & 268 & & & \\
\hline
\end{tabular}

Table 5 shows that sig $<0.05$ so that $\mathrm{H}_{0}$ is rejected, which means there is a distinction in effect between the learning model and critical thinking ability.

Table 6. The result of the comparison test

\begin{tabular}{|c|c|c|c|c|c|c|}
\hline \multicolumn{7}{|c|}{ Multiple Comparisons } \\
\hline \multirow{2}{*}{$\begin{array}{l}\text { (I) Learning } \\
\text { Model }\end{array}$} & \multirow{2}{*}{$\begin{array}{l}\text { (J) Learning } \\
\text { Model }\end{array}$} & \multirow{2}{*}{$\begin{array}{c}\text { Mean } \\
\text { Difference } \\
(\mathrm{I}-\mathrm{J})\end{array}$} & \multirow{2}{*}{$\begin{array}{l}\text { Std. } \\
\text { Error }\end{array}$} & \multirow{2}{*}{ Sig. } & \multicolumn{2}{|c|}{$\begin{array}{l}\text { 95\% Confidence } \\
\text { Interval }\end{array}$} \\
\hline & & & & & $\begin{array}{l}\text { Lower } \\
\text { Bound }\end{array}$ & $\begin{array}{l}\text { Upper } \\
\text { Bound }\end{array}$ \\
\hline \multirow{2}{*}{ PBL } & GI & 1.78888 & 1.53955 & 0.246 & -1.2424 & 4.8201 \\
\hline & Conventional & 4.00305 & 1.53106 & 0.009 & 0.9885 & 7.0176 \\
\hline \multirow{2}{*}{ GI } & PBL & -1.78888 & 1.53955 & 0.246 & -4.8201 & 1.2424 \\
\hline & Conventional & 2.21417 & 1.53106 & 0.149 & -0.8004 & 5.2287 \\
\hline \multirow{2}{*}{ Conventional } & PBL & -4.00305 & 1.53106 & 0.009 & -7.0176 & -0.9885 \\
\hline & GI & -2.21417 & 1.53106 & 0.149 & -5.2287 & 0.8004 \\
\hline
\end{tabular}

Table 6 shows that there is a significant distinction between the PBL and conventional learning models in critical thinking abilities, while there is no difference 
between PBL with GI and GI with conventional learning models. When viewed from the mean difference, the PBL and Conventional learning models have a mean difference of 4.00305 which indicates that students' critical thinking skills will increase if given PBL rather than conventional learning models.

The description above can be seen that there is an influence of the learning model on students' critical thinking ability. Problem-based learning models can create conducive learning, increase student participation in-class activities, and create student-centered learning (Wardono et al., 2016). So that students' critical thinking abilities will be better if given a problem-based learning model than conventional learning. This is in line with other research that the PBL model is more effective than conventional learning because the PBL model can improve student abilities in solving problems and developing critical thinking abilities (Ikman et al., 2016).

The GI learning model makes students understand, interpret, and build new knowledge (Yumiati \& Noviyanti, 2017). Guided inquiry makes students actively involved during the learning process (Hanson, 2005). Based on some of the previous studies above, it can be seen that the PBL and GI learning models both make students actively involved. So, it is in line with this study that the PBL model produces critical thinking abilities that are as good as the GI learning model. The GI learning model is not entirely student-centered, but the GI learning model is still under teacher guidance to solve problems so that the GI learning model produces critical thinking abilities that are as good as conventional learning.

\section{CONCLUSION}

Based on the results and discussion, the critical thinking skills provided by the problem-based learning model have a more significant positive effect than conventional learning models. Learning models that produce critical thinking skills that are as good as GI learning models and learning models that produce critical thinking skills are as good as conventional learning. So that according to the test results, the PBL learning model is more feasible to be applied in classroom learning. Therefore, it is necessary to know the appropriate learning model applied in classroom learning by students' thinking abilities. Researchers suggest that educators apply problem-based learning models. For further researchers, they can conduct research using other learning models to see the effect of the learning model on critical thinking skills. Besides, researchers can also conduct in-depth research looking for low information or critical thinking students from providing various learning models.

\section{REFERENCES}

Agoestanto, A., \& Sukestiyarno, Y. L. (2017). Analysis of Mathematics Critical Thinking Students in Junior High School Based on Cognitive Style. Journal of Physics: Conference Series, 824(1), 012052.

Alandia, R. G., Jumadi, Wilujeng, I., \& Kuswanto, H. (2019). The Effects of Web-Assisted Problem Based Learning Model of Physics Learning on High School Students' Critical Thinking Skills. Journal of Physics: Conference Series, 1233(1), 012048.

Anam, K. (2015). Pembelajaran Berbasis Inkuiri Metode dan Aplikasi. Pustaka Belajar.

Hanson, D. M. (2005). Designing Process-oriented Guided-inquiry Activities. Pacific Crest, 1-6.

Hartono R. (2013). Ragam Model Mengajar yang Mudah Diterima Murid. DIVA Press. 
Ikman, Hasnawati, \& Rezky, M. F. (2016). Effect of Problem Based Learning (PBL) Models of Critical Thinking Ability Students on the Early Mathematics Ability. International Journal of Education and Research, 4(7), 361-374.

Jacob, L. C., \& Chase, C. L. (1992). Development and Using Test Effectively. Josey-Bass Publishers.

Kusumah, R. G. T., Walid, A., Sugiharta, I., Putra, E. P., Wicaksono, I., \& Erfan, M. (2020). Construction of High School Chemistry Module, Based on Problem-based Learning (PBL) on Salt Hydrolysis Material for Gifted Students. Journal of Physics: Conference Series, 1467(1), 012047.

Meke, K. D. P., Wutsqa, D. U., \& Alfi, H. D. (2018). The Effectiveness of Problem-based Learning Using Manipulative Materials Approach on Cognitive Ability in Mathematics Learning. Journal of Physics: Conference Series, 1097(1), 012135.

Salimi, M., Susiani, T. S., \& Hidayah, R. (2017). Research-Based Learning sebagai Alternatif Model Pembelajaran di Lembaga Pendidikan Tenaga Kependidikan. Jurnal Pendidikan Sekolah Dasar, 3(1), 1-9.

Siagian, T. A., Armanto, D., \& Siagian, P. (2021). Development of Learning Device Oriented Problem Based Learning to Improve Student's Mathematical Problem Solving Skill. Journal of Physics: Conference Series, 1731, 012056.

Sulistiani, E., \& Masrukan. (2016). Pentingnya Berpikir Kritis dalam Pembelajaran Matematika untuk Menghadapi Tantangan MEA. Seminar Nasional Matematika X Universitas Semarang, 605-612.

Wahyudi. (2010). Professional Competency Standards for Teachers. Journal of Sociology and Humanities, 1, 107-119.

Wardono, Waluya, S. B., Mariani, S., \& Candra, S. D. (2016). Mathematics Literacy on Problem Based Learning with Indonesian Realistic Mathematics Education Approach Assisted E-Learning Edmodo. Journal of Physics: Conference Series, 693(1), 012014.

Widiana, R., Susanti, D., Susanti, S., \& Sumarmin, R. (2020). Need Analysis of Disseminate Handbook Based on Guided Inquiry in Animal Physiology Subject. Journal of Physics: Conference Series, 1521(4), 042013.

Yumiati, Y., \& Noviyanti, M. (2017). Analysis of Mathematic Representation Ability of Junior High School Students in the Implementation of Guided Inquiry Learning. Infinity Journal, 6(2), 137-148. 
This page is intentionally left blank.

IJEME, Vol. 5, No. 1, March 2021, 61-68. 